\title{
The Rights of Science AND the Rights of Politics: Lessons FROM the LONG- FORM Census CONTROVERsy
}

\author{
Michael Yeo
}

\begin{abstract}
One of the main issues in the long-form census controversy concerned the relationship between science and politics. Through analysis of the arguments and underlying assumptions of four influential and exemplary interventions that were made in the name of science, this paper outlines a normative account of this relationship. The paper nuances the science-protective ideals that critics invoked and argues that such conceptual resources are needed if science is to be protected from undue political encroachment. However, in their zeal to defend the rights of science critics claimed for it more than its due, eclipsing the value dimension of policy decisions and failing to respect the role of politics as the rightful locus of decision making for value issues. An adequate normative account of the relationship between science and politics in public policy must be capable not only of protecting science from politics but also of protecting politics from science.
\end{abstract}

Keywords: science, evidence, values, policy, politics, census

Résumé. L'un des principaux problèmes dans la controverse entourant le recensement détaillé concernait la relation entre la science et la politique. En analysant les arguments et les hypothèses sous-jacentes de quatre interventions influentes et exemplaires faites au nom de la science, cet article rend un constat normatif de cette relation. Il nuance les idéaux protecteurs de la science que les critiques ont invoqués et avance que de telles ressources conceptuelles sont nécessaires pour protéger la science d'un empiètement politique indu. Cependant, dans leur zèle à défendre les droits de la science, les critiques en ont réclamé plus que nécessaire, ce qui a occulté la dimension de la valeur des décisions politiques et n'a pas respecté le rôle de la politique en tant que point légitime de prise de décision sur les questions de valeur. Un constat normatif adéquat de la relation entre la science et la politique dans la politique gouvernementale doit non seulement protéger la science contre la politique, mais aussi la politique contre la science.

Mots-clés : science, preuve, valeurs, politiques, politique, recensement 


\section{INTRODUCTION}

The long-form census controversy raised important normative questions about the relationship between science and politics and resonated with other policy issues at the interface of science and politics today, such as global warming, fisheries management, and safe-injections sites. Many commentators argued that the government displayed a general disregard, or even contempt, for policy-relevant science, and a proneness to base policy on ideology in place of scientific evidence. The government was accused of lacking in respect for the integrity of science and, with reference to Statistics Canada, of intruding into a domain of decision making proper to science. Critics worried about the influence of ideology or politics on, or encroachment into, matters they believed should be left to science to decide autonomously, free of political interference.

My analysis probes four critical texts that received significant media coverage, influenced public debate, and exemplified views expressed by numerous other commentators. Two main norms that critics assumed or invoked in their critique of the government's actions stand out: that public policy should be based on relevant scientifically determined evidence and that science should be free of political interference in the generation and interpretation of such evidence. These norms connect with such ideals as "value-free science," "objectivity," "neutrality," and the "factvalue" distinction at the core of the traditional or orthodox view of science that is much contested today in several disciplines, including ethics, philosophy of science, and science studies. ${ }^{1}$

The normative arguments against the government's actions were indeed somewhat simplistic in the way science was opposed to policy and evidence to ideology. Such distinction as can and should be made between science and policy is considerably more complicated than these arguments would have it. Nonetheless, carefully nuanced and qualified, the science-protective norms and concepts strategically deployed in these four critical texts are defensible at the level of theory. Moreover, an important lesson to be taken from the controversy is that at the level of practice some such normative framework is necessary to delimit a zone of autonomy for science in policy and thereby to protect science from undue political interference.

However, a robust normative account of the relationship between science and politics in public policy needs to concern itself not only with protecting science from politics but also with protecting politics from science. In their zeal to defend recognition and respect for the rights

1. Recent works of note include Latour 2004; Collins and Evans 2009; Douglas 2009; and edited volumes by Kincaid et al. 2007; Rasmussen 2005; and Selinger and Crease 2006. 
of science in public policy decision-making, critics sometimes failed to give due recognition to the essential dimension of values in public policy, and to the rights of politics as the proper locus of decision making for value issues.

\section{Evidence Ideology and Values}

The norm that scientific evidence relevant to policy decisions should figure in policy decision-making, although open to interpretation, is hardly debatable. However, the phrase "evidence-based policy" lends itself to sloganism, especially as deployed in rhetorical contexts to advance a favoured policy outcome.

Evidence-based policy emerged as a central theme and rallying cry from the beginning of the controversy. At various points the significance of evidence in policy decision-making was constructed in such a way as to eclipse or displace the dimension of values. The juxtaposition of evidence with ideology, repeated in several formulas, had this effect. The term "ideology" was used in a casual, ordinary language sense as a term of derision denoting something like the hidden operation of unsavoury ideas, as if various experts partisan in the debate did not have ideological agendas, and as if appeals to anything but evidence could only be ideological. Slogans to the effect "evidence, not ideology" framed the debate throughout, as if on the one side were those who believed that policy should be based on evidence and on the other those who would base policy on ideology, at best ignoring evidence, at worst manipulating it to support policy options arrived at on ideological grounds.

\section{Evidence versus Ideology: The CMAJ Editorial}

The juxtaposition of evidence and ideology initially emerged as a charge against the privacy rationale the government offered for its policy decision to abandon the long-form census. Early in the controversy, this was the focus of a Canadian Medical Association Journal (CMAJ) editorial with the headline "Ideology trumps evidence with new voluntary survey" (Cohen and Hébert 2010). The editorial categorically dismissed the privacy rationale, noting Statistics Canada's rigorous data protection measures and the government's failure to "produce letters of complaint or evidence of public outcry about intrusiveness." Since the stated rationale was deemed not credible, there must have been some other rationale, unexpressed or concealed, behind the government's decision. " "The

2. The privacy rationale offered by the government may well have been a front for a less savoury motivation. Regardless, there was indeed a legitimate privacy issue, as Yeo (2010) argues referencing Statistics Canada's (2009) own definition: "Privacy is the right to be left alone, to be free from interference and intrusions. It includes the right of 
Harper government," the editorial concluded, "appear[s] to have made a decision based on ideology rather than evidence." Many commentators speculated as to what this ideology might be; a very plausible and wellreasoned theory was advanced by political scientist Paul Saurette (2010).

Although the editorial applied the evidence versus ideology trope specifically to the government's suspect rationale for the policy decision, it also extended it to its substance. By abandoning the long-form census, the government would be depriving itself of an essential tool necessary for generating policy-relevant evidence across a range of domains. The decision thus "undermined evidence-based decision-making in Canada" (Cohen and Hébert 2010). Driven by ideology in place of evidence, the decision was indicative of a general orientation to policy lacking in regard for evidence.

The evidence versus ideology theme was picked up by many commentators, including Globe and Mail columnist Jeffrey Simpson (2010), who saw the issue as a "fight about rational decision-making that requires the best fact-based evidence available against a reliance on ideological nostrums that scorn facts and reason when they stand in the way of those nostrums." Moreover, whereas the CMAJ editorial merely argued that the government's decision would have the effect of compromising the usefulness of data essential for policy purposes, other critics opined that this was its intent.

The evidence versus ideology construction is problematic in several respects. For example, one could counter that evidence, and the experts who claim to speak for it, are not and cannot be insulated from ideology or politics in the way that the construction would have us believe. The rhetoric that frames one's opponent in debate as being ideological issued from a standpoint presumably free of ideology and based solely on science and evidence - could itself be characterized as ideological. Ideals such as objectivity, neutrality, and freedom from politics or values bias that were assumed or deployed by critics reflect a modern or traditional view that is considered naïve, simplistic, and untenable in much theorizing in science studies and other literatures. ${ }^{3}$

Certainly some of those who castigated the government for being ideological — including various experts — were at least partly motiv-

individuals to determine when, how and to what extent their information is shared with others. The collection of information from respondents by Statistics Canada is, by its nature, a privacy-intrusive activity" [Italics added for emphasis].

3. It is noteworthy that criticism of the traditional view of science, although pervasive in the academic literature, did not figure in the public debate. Perhaps those who disagreed with the government and would otherwise judge ideals such as objectivity and neutrality to be naïve were happy to see them put to work in defense of science and against the government? 
ated by extra-scientific or political values as concerns what sorts of policies Canada should have across a range of policy issues, and less than objective or neutral. In arguing for the continuation of the long-form census critics appealed not just to expert opinion that the data generated from the voluntary survey would be significantly inferior but also to the value of having reliable statistical data available for deciding any number of policy issues. No doubt some had positions on ancillary policy issues and believed that statistical evidence would help push these issues toward their favoured outcomes. However, nothing in the traditional view or in notions such as objectivity and neutrality is undermined by the fact that scientists, like anyone else, may hold value or political biases more or less passionately and advance them in the public argument. The issue arises only as concerns ideology and values in the conduct of science as such.

Moreover, defenders of the traditional view such as Raatikainen (2006) and Kitcher (2001) recognize that there are values internal to the practice of science (e.g., intellectual honesty) which play a legitimate and necessary role in the conduct of science, and that moreover even external values play a legitimate role in such matters as the choice of which research issues to pursue and limitations on the conduct of science insofar as it may impinge on human rights (e.g., as in research ethics). ${ }^{4}$ What is problematic from the traditional point of view is when external values in scientific or evidentiary determinations bias the evidence in the direction of a preferred policy outcome.

Two main lines of argument against the traditional view are often run together. One is that scientific determinations are in fact fused with external values. To be sure, even with respect to expert issues expert opinion can be influenced by the expert's values, and the more so the more ambiguous or indeterminate the evidence, even if the expert is genuinely committed to deciding the issue on scientific grounds alone. One reason experts sometimes disagree is that their interpretation of the evidence is influenced in the direction of the values they hold and of the policy outcome they prefer based on those values. Such influence, or even the suspicion of it, contributes to distrust of experts. Indeed, it may be that the disregard or contempt for experts that critics detected on the part of government was informed by some such suspicion or even by the postmodern belief that, in the interface with policy, science is necessarily

4. Kitcher's (2001:41) defense of the traditional view ("the view of the scientific faithful") is qualified in view of criticisms. However, he endorses its main tenets, arguing, for example, that we should not "suppose that ideals of objectivity are misguided and that, because of rampant underdetermination, scientific decisions are made, perforce, by invoking moral, social and political values" (2001:85). 
ideological to the point that it is unavoidably saturated with ideology and disguised value judgments.

However, if it sometimes happens that science or evidence is influenced by the scientist's or expert's values related to his or her preferred policy outcome, or of political masters using experts as puppets, normatively speaking - accepting the norms that critics assumed - it ought not to be. It is possible in some significant measure, and virtually constitutive of the scientific attitude, for scientists and experts to bracket their own values in practising science or making expert judgments. Controls to eliminate, or at least reduce, such bias or bias that could creep in undetected from other sources are virtually constitutive of the ethos and culture of science. Even theorists who deny the possibility of "value-free science" recognize the reduction, if not elimination, of value bias as an important ideal. Veatch (2005:221), for example, seeks "strategies for neutralizing the values of scientific experts." Probably no one would disagree with seeking to neutralize the potential values influence of funders or advocacy groups on experts.

A second line of argument against the traditional view has it that in some instances external values rightly do and should influence scientific or evidentiary determinations in some range of cases. Douglas (2009), who gives a comprehensive review of this theoretical debate in the philosophy of science, has a carefully nuanced and qualified position. However, notwithstanding that she positions herself against the traditional view and rejects outright the value-free ideal, in all but very narrowly defined circumstances (e.g., in deciding what to claim when evidence is underdetermined, and the consequences of being wrong are significant) her view is as averse to value bias as is the traditional view.

Even though their arguments were insufficiently nuanced, critics of the government's actions were right to appeal to the science-protective normative ideals that they did, and moreover would have lacked grounds for critique if they had not. I take issue with the evidence versus ideology construction not because it assumes a naïve view of science but because it does not allow space for values and politics.

The term "ideology" as juxtaposed against evidence throughout the controversy was clearly pejorative: evidence is good, ideology is bad. This can be defended to a point, but in its simplicity obscures as well as reveals. To be sure, critics were right to say that policy issues should be decided based on the best evidence available (insofar as this evidence is relevant to the policy issue). And the normative ideal that scientific or evidentiary determinations should be insulated from biasing policy or personal values external to the scientific enterprise is essential to science and something to be striven for. However, although some policy 
issues come down to evidentiary issues, no policy issue turns on evidence alone.

Ultimately, policy issues necessarily and rightfully refer to some good or other in light of which evidence is more or less relevant. Often, the good to be achieved and the evils to be avoided are directly contested, in which case the policy issue amounts to a choice among competing goods or evils; different policy options will express different value orientations or weightings. In some instances, the good to be achieved is so compelling and widely endorsed that it is uncontested or taken for granted. In such cases the policy issue may reduce to, and instrumentally turn upon, a scientific or evidentiary issue. The debate among policy options turns on a scientific or technical debate about how best to achieve a given or assumed end. In yet other instances, and not infrequently, there are indeed competing values in play, but not explicitly. Debate that ostensibly occurs on grounds of evidence or science is indirectly about values. Science or evidence becomes a proxy battleground for values debate as the interpretation of science or evidence is illicitly infused with values to favour a policy option preferred independent of the science or evidence.

The evidence versus ideology construction obscures the complex interplays between science and values in public policy, setting up an ethically charged exclusive disjunction according to which a policy decision is either based on evidence or ideology. Since values have no rightful or legitimate place on the side of evidence, they could only figure on the side of ideology; the way ideology is negatively charged in the disjunction, this means that they could only be illegitimate. However, to say that policy values have no legitimate role in evidentiary or scientific determinations as such is not to say that they have no legitimate role in policy. Values, and ideology even (if with theorists of ideology like Mannheim [1936] and Ricouer [1984] we allow that ideology also carries a nonpejorative meaning not essentially associated with distortion or falsity), are essential to policy insofar as policy is ultimately about some good to be achieved or evil to be avoided.

\section{Evidence and Expertise: The Nature Editorial}

In the course of the controversy, the evidence versus ideology theme was amplified as expert after expert lined up to contradict the government's claim - an empirical or evidentiary one, to be decided on scientific or evidentiary grounds, the traditional view would have it - that the National Household Survey could produce data of quality comparable to the 
long-form census. ${ }^{5}$ There is an obvious link between scientific evidence and scientific expertise. Scientific experts are people whose training and experience especially qualifies them to pronounce on certain evidentiary issues. The government's alleged disregard for evidence was perceived as going hand in hand with disregard for expertise.

Focusing on expertise and experts highlights the question of who has rightful authority for decision making with respect to a given issue. The proposition that government should take into account scientific evidence relevant to a policy decision and respect the authoritativeness of experts in rendering this evidence gives science its proper due. However, this does not extend to the policy decision, which even if based on evidence must also, and ultimately, be based on values. Experts may hold values and have value-based opinions about this or that policy issue, but their values and value-based opinions are not authoritative in the way that their scientific or evidentiary determinations are.

Public pronouncements made by experts often concern both the scientific or evidentiary component of a policy issue and values judgments, without distinction. When this occurs, such authoritativeness and deference as is appropriate for the expert qua expert may be transferred to him or her (or assumed) in matters of value beyond expertise. What is in fact a value judgment may be issued and received with the prestige and authority that is rightly due the expert in strictly expert matters.

Veatch (1973) has referred to this phenomenon as "generalization of expertise." It has to do not with the inappropriate intrusion of values into science but with the intrusion of science, or at least the prestige and authority that it rightly enjoys, into value issues. The opinion of a statistics expert that a voluntary National Household Survey will yield data significantly flawed and inferior compared to the mandatory longform census is properly an expert opinion. However, the opinion of the statistical expert that we should therefore maintain the mandatory longform census is not an expert but a value judgment. The statistical expert who makes such a judgment is not doing so qua expert. Nonetheless, the pronouncement may be issued or received with such prestige and authority as the expert rightfully enjoys qua expert, or even exploited by others no matter how scrupulous the expert is in delimiting the scope

5. Expert arguments about the relative deficiencies of a voluntary survey, and careful analyses of the likely negative effects of abandoning the long-form census, are helpfully reviewed in Veal 2010; Green and Milligan 2010; and Dillon 2010. The current Chief Statistician is pretty much alone among his peers in asserting that "there's no scientific reason for saying this [the voluntary survey] is going to be fundamentally flawed" (Chase and Grant 2010). However, quoted on this subject only a month or so later, he was a little more circumspect: "When we compare this to the mandatory census, it's not realistic to expect that we will get equal data. But will it be acceptable and usable?... Potentially yes" (Bruno 2010a). 
of his or her expertise. Expertise in one domain is generalized to expertise in other. Discussing the "rise of expert authority" in contemporary society, Brooks (2007:25-26) notes that often "expertise and the expert are used in magical ways. Far from promoting rational policy debate, experts offer, and their use itself can act as, incantations that casts a spell of scientific authority over the viewpoints they support."

One's opinion about the rightness of the government's policy decision ultimately will depend on one's values. And that is true also for the experts who advocated as a matter of policy that the long-form census should be maintained. Their expertise in the scientific evidence relevant to the policy issue does not give them any special authority to pronounce on the policy issue because the policy issue is not reducible to evidentiary or expert issues alone. Expertise in the evidence and scientific issues relevant to the policy issue does not carry over into expertise in the policy question as such insofar as the policy question necessarily involves a value judgment.

Generalization of expertise occurs in the passage below from an editorial in Nature (2010) titled "Save the Census." The editorial begins by noting that the census "incident comes amid a growing sense of unease about the right-leaning Canadian federal government's apparent disregard for science-based policy." The government's actions with regard to the census are thus seen as part of a pattern and linked to a variety of other policy issues.

The country continues to support the mining of asbestos and its export to the developing world, despite repeated calls to ban the toxic substance and cries of protest from the medical community. Canada has been one of the most obstructive countries at climate-change talks, and continues to be protective of its development of the tar sands one of the world's dirtiest sources of oil. The federal government has fought against maintaining the supervised injection facility for drug addicts in Vancouver, despite staunch protest from the medical community and studies showing that such programmes are helpful. ${ }^{6}$

6. Defining the term "helpful," and even more deciding how helping should be balanced in connection with other possibly competing values, involves value judgment and cannot be decided by evidence; however, assuming a given definition, whether or to what extent this or that course of action is helpful or more helpful than some other is an expert judgment and does turn on evidence. The recent unanimous decision of the Supreme Court of Canada (2011) concerning Insite was widely celebrated as a victory for "evidence" over "ideology." However, the government's case before the court did not rest on scientific evidentiary issues but on a moral argument to the effect that such harm as IV drug users might be subject to is a consequence of their own choice and not of government policy. The Court rejected this moral argument and rested its decision not on evidence but on a legal/values norm: "The Minister's failure to grant a s. 56 exemption to Insite engaged the claimants's. 7 rights and contravened the principles of fundamental justice." 
The policy issues referenced here are ones for which scientific evidence and expertise are relevant. However, the editorial would have us believe that evidence and expertise are not just relevant to these policy issues, but also determinative, as if government owes deference to experts (in this case, the "medical community") not just in matters of science, but also policy.

There is a fallacy at work here. When the medical community calls for this or that policy option regarding any of these controversial policy issues, this is not an expert judgment properly speaking. For example, "What are the effects of asbestos?" is an expert question; "should its import be banned?" is a policy question. In deciding, it will be quite appropriate to weigh the negative health impacts, ideally as determined by the best evidence available, against other value considerations. On one side of the policy issue or the other, the decision will involve a value judgment. With respect to such value judgments, the medical community or people expert in relevant science do not have any special authority. If such rightful authority as they may have with respect to the science issue is generalized, the values in play are masked by science and the rightful role of the political is encroached upon.

To suppose that government should defer to experts in expert matters is one thing. However, to suppose, as the Nature editorial does, that government should modestly accept a policy option preferred or recommended by those expert in the science relevant to the issue just because they are experts is to obscure, and privilege, the values, however commendable, that the experts happen to hold. To say this of course is not to justify government policy in these areas. It may be that all things considered the values informing the policy options the medical community recommend would make for better public policy. The point is that even if one grants this, such recommendations are in the domain of values and politics, and exceed the scope of expertise for which deference may be due the medical community.

\section{The Integrity of SCIEnCE}

During the controversy the evidence versus ideology construction, and concern about the appropriate role of evidence and expertise vis-à-vis politics in policy decision-making, shaded into related issues concerning the integrity of science, with Statistics Canada taken as representative of science in general. Several critics expressed the worry, or complaint, that the government was not merely disregarding or even scorning science, but interfering with or encroaching upon it in such as way as to threaten its integrity. 
Initially, the integrity issue emerged in connection with the government's defence of its decision in the face of significant opposition as the minister responsible created the impression that its decision enjoyed the support of Statistics Canada, as if Statistics Canada had advised that the National Household Survey could produce data of quality more or less on par with the long census. This is what provoked the resignation of the chief statistician, Munir Sheikh.

In his July 21 letter of resignation the chief statistician did not mention integrity or explicitly state a reason for resigning. He limited his remarks to a comment on what he called "a technical statistical issue which has become the subject of media discussion," namely, "whether a voluntary survey can become a substitute for a mandatory census" (Sheikh 2010). He felt it necessary to publicly and unequivocally express his expert opinion that it can not. However, reading between the lines and taking his remarks in context, others perceived something more than a "technical statistical issue" at stake. "This was about the integrity of Statistics Canada and of the public service," argued Alex Himelfarb, former Clerk of the Privacy Council, in an opinion piece discussing the resignation (Himelfarb 2010).

Integrity is indeed the appropriate concept to describe the circumstances surrounding the chief statistician's resignation, but it is a complicated concept and needs to be unpacked carefully. At the core of the controversy there was, in the chief statistician's words, a "statistical technical issue" - a properly "scientific issue," I would add. The government expressed a claim about that technical issue, namely that the voluntary survey could be an adequate substitute for the long-form census. If that were all the government claimed, one could accuse the government of ignoring evidence and overwhelming expert opinion to the contrary, or even of illicitly infusing the evidentiary issue with undeclared values. However, by itself that would not have been an integrity issue for Statistics Canada or the chief statistician. The issue of integrity arose because the government imputed its scientific claim to Statistics Canada, as if it had received it on the advice and authority of Statistics Canada. The government, it appeared, was using Statistics Canada and the authority due it as expert in matters of statistics to rationalize a policy decision as if it were based on science when in fact it was not. The chief statistician believed it was necessary to clarify his position on the technical issue precisely because he believed the government had misrepresented his agency's position and advice in matters in which it was expert, imputing an expert opinion to Statistics Canada that in fact it did not hold or endorse. 
Among other things, the integrity of science norm means that science should settle its own questions independently, free from external influence in the conduct of science and in the formation and representation of its expert opinions. This norm would also be violated if in conducting science or forming expert opinions scientists were influenced by any biases that they might hold in the direction of a policy option favoured for extra-scientific reasons. This may have been a concern of government, but the concern of critics had to do with external political influence. Had Statistics Canada expressed the opinion imputed to it by the government, believing it to be false and bowing to political pressure, it would thereby have compromised its integrity and undermined trust in its authority qua science. If government coerced it to do so, such coercion would have been undue political interference with or encroachment into matters of science. Had the chief statistician not contradicted the government's claim that it was acting on advice from Statistics Canada, it would have appeared to other experts, believing that this advice was scientifically unsound, that Statistics Canada was either incompetent or a puppet of politics. This is more or less the explanation Mr. Sheikh gave July 27 at the Standing Committee on Industry, Science and Technology:

The reason I resigned ... was that when doubt began to be expressed about the nature of the advice we gave, which to any statistician would come across as not the work of a statistician, I came to the conclusion that I cannot be the head of an agency whose reputation has suffered. (Canada, Parliament 2010)

If disregard for the norm that policy should be based on relevant evidence makes for bad policy, disrespect for the integrity of science norm additionally makes for bad science. This norm is more fundamental because if science lacks integrity the norm that policy should be based on evidence that science produces or that experts render has no force. Violation of the integrity of science norm is therefore more serious, and appeal to it to ensure that science is protected from external politics and to secure its borders is more compelling.

However, during the controversy, rhetoric to the effect that the integrity of Statistics Canada was under threat from undue political interference was sometimes used to claim more for science than is strictly its due. In the name of protecting science from politics, territory proper to politics was claimed for science.

\section{Ideology, Autonomy and Integrity: The Thompson Piece}

In an opinion piece published by the Mowat Centre for Innovation titled "Ideology, Autonomy and the Census," academic Debra Thompson in- 
voked the rhetoric of integrity with much broader application than to the narrow issue analyzed above concerning political interference in the characterization of Statistics Canada's expert opinion or advice (Thompson 2010a). Indeed, she does not even mention that issue and is concerned rather with threats to integrity in the conduct of science as such at Statistics Canada. She speaks of a "forced battle between autonomy and ideology," referring to "the interference of ideologically-saturated decisions about who and what should be counted, and how this counting should take place." Noting that there had been "grave concern over how the Harper government's decision will impact the quality of data produced," she adds: "Equally disturbing, however, is what this means for the future of the integrity of Statistics Canada."

Thompson does not clarify just what she means by integrity but speaks as if it were the same as autonomy. She argues that in view of the long-form census decision Statistics Canada's "institutional autonomy must be strengthened" and suggests various reforms to give it greater independence from politics. Although she does not say precisely how the government threatened Statistics Canada's autonomy or integrity, quoting the UN Statistical Commission she implies that its actions constituted political interference in how Statistics Canada conducts its scientific affairs: "Compilation and release of data should be free from political interference, so as to ensure impartiality of the national statistical office" (Thompson 2010a). In a related article (Thompson 2010b:378), she further elaborates the norm she believes to be threatened, noting that the "census and the statistical agency responsible for it are supposed to be ideology free and non-partisan."

Thompson's normative view of Statistics Canada is arguably the orthodox view and was widely assumed by critics throughout the controversy. As contentious as concepts like impartiality and ideological neutrality may be, they are defensible and appropriate norms for Statistics Canada, and indeed for science in general. If there is a sense in which science, and especially the census, is not or cannot be entirely free of political influence or ideology, it is important to distinguish different ways in which this influence occurs and at what point it constitutes interference or threatens the integrity of science.

To be sure, the census in Canada has not been the subject of partisan political controversy as it has been in other jurisdictions, and notably the United States (Anderson and Fienberg 2001). Nonetheless as Skerry (2000) claims for the American context, the census is inherently and properly political. In Canada, this is also true at least in the sense that the questions asked are guided by policy values and, in the case of Statistics Canada, approved by cabinet, as Thompson herself notes. However, if 
the politics involved in deciding what questions need to be answered for the purposes of policy is political, or even problematic, it is not obvious that or how this constitutes political interference or threatens the integrity of science, provided that science is left to its own devices to answer the questions according to its best lights. In any event, that has been and is the status quo in Canada.

The politics involved in deliberately avoiding or suppressing evidence-generating questions out of apprehension that the evidence produced will undermine preferred policy options is considerably more problematic. This appears to be Thompson's primary concern, echoed by numerous commentators who believed that the government intended that the data from the voluntary National Household Survey would be so unreliable as to be unusable, in effect deliberately suppressing science and evidence.

The interface between politics and science in the determination of priorities for policy-relevant research is thorny, particularly if the worry is that research questions are not just neglected but deliberately avoided because evidence-based answers are politically undesirable. However, under conditions of public funding, and especially as concerns a publicly funded scientific agency empowered by and with law to require citizens to participate in research, it would be politically irresponsible for government to surrender to science the right of setting priorities for research to inform public policy. Mr. Sheikh very clearly and starkly expressed this normative position before the Standing Committee, clarifying also the line that must be drawn to protect the integrity of science:

The government has every right to go down this path. Nobody is disputing that the government has the right to do whatever it wants, and our job is to implement the government's decision - as long as we all understand that the statisticians are saying that the quality of data will be lower. (2010)

Even if, as is unlikely in my view, the government's decision to replace the long-form census with a voluntary survey was deliberately intended to produce data of such poor quality as to be unusable, it is not obvious that this would constitute political interference or threaten the integrity of Statistics Canada, provided, as Mr. Sheikh puts it, "we all understand" what expert opinion has to say about the science, and government does not muzzle science or treat it as its puppet.

If Thompson's invocation of the integrity of science norm exceeds what Mr. Sheikh rightly insists upon, it is because she demands too much for science vis-à-vis politics. Elaborating on how the "institutional autonomy" of Statistics Canada should be strengthened in view of the long-form census decision, she writes that "The statistics produced 
through the census and other surveys must be objective and accurate" (Thompson 2010a). The proposition that science should be objective is one thing. If we parse this to mean that the compilation or interpretation of statistics should not be influenced by a policy bias in the direction of one or other favoured policy option or outcome, it concerns a norm that is essentially constitutive of science. The influence of such a policy bias on science, whether that of the scientists concerned or imposed upon them by external coercion or enticement, would threaten its integrity.

That science should be "accurate" is quite a different proposition. Accuracy is of course a proper scientific ideal, but it is not constitutive of science in the way that objectivity or impartiality is. There are many limitations, of various sorts, that impede accuracy. The accuracy that can be achieved in measuring the distance of intergalactic phenomena or the velocity of subatomic particles will be limited by available technologies, as will be the accuracy of medical diagnoses or of weather predictions. In the case of population statistics, accuracy will be limited by many factors, from sample size to deception on the part of respondents. Science makes do with such accuracy as is possible given the limitations under which it operates; integrity is not compromised by these limitations and the failure to achieve perfect accuracy provided that whatever conclusions may be drawn are qualified in view of the limitations. In some cases, these limitations may be significant enough that no reliable conclusions can be drawn, in which case the integrity of science is preserved provided science does not claim otherwise.

Moreover, even expressly political limitations or constraints on science that impede accuracy do not necessarily compromise scientific integrity. No doubt accuracy in many natural and social sciences could be enhanced if anyone entering a hospital, school, or prison was conscripted into research or experimentation. However, this would contravene significant moral principles, expressed also in law, that forbid this. Such limitations of science in the name of values can indeed diminish accuracy but do not for that reason compromise the integrity of science.

The autonomy of Statistics Canada, and of science in general, visà-vis political influence that would compromise its objectivity or impartiality, is necessary for its scientific integrity. However, to demand autonomy with respect to political influence that could limit or even compromise accuracy cannot be justified in the name of integrity for science. Indeed, not to limit science with respect to decisions bearing on its accuracy would be to surrender to it territory that rightly belongs to politics and would undermine the integrity of politics. 


\section{Integrity and Scientific Method: The Open Letter}

The question of integrity, whether of science or of politics, depends on distinguishing decisions that are proper to science, to be made on scientific grounds free of political influence, and a range of decisions that are proper to politics, to be made based on some weighting of values and interests and not masked as expert or scientific judgments. However, if this distinction is plain in some cases, with agreement that this or that issue is properly an expert issue and this or that a political one, in other cases what rightly belongs to one or the other is ambiguous. This is especially so for issues that are both scientific or technical and political.

In an open letter to the Prime Minister, four high level former civil servants, including former chief statistician of Canada Ivan Fellegi, argued for reforms to clarify the scope of responsibility of Statistics Canada vis-à-vis politics (Cappe et al. 2010). In speaking of what is at stake they do not use the term integrity, but the terms they do use - "credibility," "reputation," "public confidence," and "essential trust of the public" - address the same concept. (In a subsequent interview, Fellegi is much more direct and explicit about the threat to integrity, and is quoted to say that without Statistics Canada's integrity "we might as well not exist" [Bruno 2010b].) They begin their letter claiming that "issues have arisen that put the well-earned credibility and respected international standing of Statistics Canada at risk." While noting and accepting that Statistics Canada is not "absolutely independent" and that "the governor in council" determines "the questions of the census," they claim that "the responsibility of the chief statistician for methodological and technical issues, implicit to date, has been called into question." To maintain credibility and trust in Statistics Canada, they "call on the government of Canada to reconfirm Canada's commitment to the UN Fundamental Principles of Official Statistics and to amend the Statistics Act to make clear that the chief statistician is responsible for issues of methodology and technique."

The clear implication of their letter is that the government's decision to abandon the long-form census and replace it with a voluntary one constituted an intrusion into the proper sphere of decision making of Statistics Canada. Presumably, this is because it concerned "issues of methodology and technique" which, according to the letter writers, fall within the responsibility of the chief statistician to determine according to scientific, expert criteria. They cede responsibility to politics in the matter of approving the questions that Statistics Canada should answer but draw the line as concerns the choice of methods or techniques for obtaining scientifically determined answers to whatever questions have been politically determined. 
Whether the answers to a given set of questions are likely to be more accurate and reliable if determined by a mandatory long-form census or a voluntary survey is indeed a technical issue, as Munir Shiekh called it. However, whether to go with the one or the other, all things considered, is not. To be sure, voluntariness as against mandatoriness can be construed as an issue of method or technique. However, the issue concerns much more than method or technique insofar as it impinges on other values. As a matter of method, a physician may decide in a given circumstance that the most effective way to treat a cancerous tumour is surgery, even if radiation or chemotherapy would also be effective in some measure. One could say that this would be a choice among competing methods for accomplishing the same objective. However, this would not mean that, the objective having been set, the decision about method belongs to the physician. The tumour is the patient's after all, and the patient has rights as concerns choices among competing methods for treating it.

The authors of the Open Letter invoke the compelling integrity of science norm in scoping the responsibility of Statistics Canada to preserve for it independence from politics in issues of method and technique, as if the involvement of politics in such issues would constitute integrity-threatening intrusion into, or interference with, matters that properly belonged to science and should be left to science to decide. That would certainly be the case if political involvement in issues of method were toward influencing the outcome of a scientific study in the direction of a scientific conclusion favoured because it supported a policy option preferred for extra-scientific reasons. However, to the extent the choice of method directly impinges on values, the decision is not just methodological, and falls also within the rightful domain of politics. Value conflict can furnish legitimate reasons for limiting the autonomy and scope of responsibility for science. The authors of the Open Letter grant this in their proposed amendment, allowing that, in addition to "scientific principles," the chief statistician should also be guided by "professional ethics" in determining the "methods and procedures for the collection, processing, storage and presentation of statistical data" (Cappe et al. 2010). One can debate what range of value decisions should be left to self-regulating "professional ethics" and its politics and what range to government regulation and influence, but such debate is clearly a values debate in the domain of politics, not science.

\section{Conclusion}

The possibility of rigorously distinguishing between science and politics has been undermined by challenges to the fact-value distinction and con- 
cepts like "objectivity" and "neutrality." Although it has been beyond the scope of this paper to engage the extensive literature on these issues in any detail, I have argued that this distinction and related concepts, properly nuanced and elaborated, are theoretically defensible. If science and politics or facts and values are often or even typically entangled, and even if in the final analysis all science and any facts are value-laden or shaped in some measure by values, it is possible nonetheless to distinguish and disentangle them in cases that matter. Much of the work that ethicists do in a variety of applied settings and contexts involves disentangling or distinguishing the components of a given issue that are technical or scientific from those that are political or values-based.

At any rate, some principled way of distinguishing science and politics, or facts and values, is necessary for the practical purpose of delimiting the proper or rightful role of science and of politics in decision making concerning matters of public policy in order to protect each from encroachments by the other. ${ }^{7}$ Indeed, I believe that the adequacy of theoretical accounts of the relationship between science and politics can and should be tested with reference to whether and how well, in practical terms, the account enables or undermines the ability to identify and criticize such encroachments. The long-census controversy is an excellent testing ground for this purpose.

Reflecting with concern on how the concept of "fact" has been relativized and undermined in public debates about global warming and other "artificially maintained controversies" Bruno Latour, one of the leading figures in postmodern or postpositivist critiques of science and of the fact-value distinction, writes:

I myself have spent some time in the past trying to show "the lack of scientific certainty" inherent in the construction of facts. I too made it a "primary issue." But I did not exactly aim at fooling the public by obscuring the certainty of a closed argument — or did I? Still, I'd like to believe that ... I intended to emancipate the public from prematurely naturalized objectified facts. Was I foolishly mistaken? Have things changed so fast? In which case the danger would no longer be coming from an excessive confidence in ideological arguments posturing as matters of fact - as we have learned to combat so efficiently in the past - but from an excessive distrust of good matters of fact disguised as bad ideological biases! While

7. In his analysis of science and policy, Fafard (2008:16) asserts: "Maintaining a distinction between facts and values is essential in health and natural sciences. It is this distinction that allows scientists and health professionals to participate in policy debates and take the position that what they bring to the table are facts based on careful amassing of research evidence." Fafard seems somewhat troubled and even apologetic that this rather old-fashioned view is out of step with "much of the work in science and technology studies." So much the worse for this work, I would say. 
we spent years trying to detect the real prejudices hidden behind the appearance of objective statements, do we now have to reveal the real objective and incontrovertible facts hidden behind the illusion of prejudices? (Latour 2003:274)

No doubt, critics who cried foul at the government for undermining the integrity of science deployed traditional science-protective norms and concepts loosely. However, it is not surprising that they turned to these norms and concepts because without recourse to them they would have had no grounds for objection to the government's actions, which actions may very well have been premised on a view (ironically similar to some postmodern views) that science is disguised ideology!

Latour is not the only critic of the traditional view who has had cause to rethink critique of the traditional view of science in view of how postmodern cynicism about science plays out in policy debate. Recent work on the sociology of expertise by Collins and Evans (2007) can be read as a corrective to sweeping or glib statements in what they call the "second wave of science studies" that undermined the ideals of the traditional view that characterized the first wave. The "third wave" they propose rehabilitates traditional ideals in some measure and urges that "we must leave a space for certain types of expertise to be recognized independently of politics" (2007:8).

Such a space is necessary not only to protect science from politics, but to protect politics from science. Collins and Evans (2009:8) write:

Failing to make a distinction between science and technology, on the one hand, and politics, on the other, leads to the stark choice between technological populism, in which there are no experts, and fascism, in which the only political rights are those gained through supposed technical expertise.

"Scientism" or "technocracy" would be better terms than "fascism" to describe the danger of science eclipsing or usurping the rightful role of politics by confusing, or at least failing to distinguish, matters of fact, of which science is the rightful arbiter, and matters of value, of which politics is. ${ }^{8}$ In this regard, the four critical interventions analyzed in this

8. In the case of the $C M A J$ and the Nature editorials in particular, another term would be what Russell et al. (2008:40), critiquing the ideology of "evidence-based policy," refer to as "the naïve rationalist" model of policy making, by which they mean "[t]he idea that policy-making is all about finding and implementing best research evidence, and that the answer to improving policy-making is to identify and overcome barriers to smooth flow of best evidence into practice." This ideology has been pervasive not only in recent health policy discussion (Farard 2008) but also in health policy studies, although this may be changing. In a review of five recent books in the field of policy studies, Hambrick (2011) notes: "Perhaps the principal theme among these books is the 
paper are far less worrisome for lack of nuance in the norms they deployed in defending the rights of science vis-à-vis politics than in their failure to recognize the limits of science and allow a space for the rights of politics.

An adequate normative account of the relationship science and politics needs conceptual resources sufficient to distinguish science and politics, and to set limits to both in order to protect the rights of each from the encroachment of the other. Of course policy should be informed by evidence, and evidentiary determinations and the production of evidence for policy should be insulated from politics to the extent possible, as the government's critics would have it. But policy decisions are ultimately values decisions, and what we should or should not do in view of evidence, or whether a method of producing evidence that impinges on important societal values is acceptable, is a political, and not a scientific question.

\section{REFERENCES}

Anderson, Margo and Stephen E. Fienberg. 2001. Who Counts? The Politics of Census-Taking in Contemporary America. Revised paperback ed. New York: Russell Sage Foundation.

Brooks, Stephen. 2007. The policy analysis profession in Canada. In Laurent Dobuzinskis, Michael Howlett, and David Laycock, eds., Policy Analysis in Canada: The State of the Art. Toronto: University of Toronto Press.

Bruno, Jessica. 2010a. Next census gathering has begun, passed 'point of no return', says new StatsCan chief. The Hill Times Online, 14 March. Available at: http://hilltimes.com/page/view/census-03-14-2011

2010b. Without Statistics Canada's integrity 'we might as well not exist': Fellegi. The Hill Times Online, 27 Sept. Available at: http://www. thehilltimes.ca/page/printpage/civcirc-09-27-2010

Canada. Parliament. 2010. House of Commons. Standing Committee on Industry, Science and Technology. Minutes of Proceedings. 3rd sess., 40th Parliament, Meeting No. 29, 27 July. Available at: http://www.parl.gc.ca/ HousePublications/Publication .aspx?DocId $=4648039 \&$ Language $=\mathrm{E} \& \mathrm{M}$ ode $=1 \&$ Parl $=40 \&$ Ses $=3$

Canada (Attorney General) v. PHS Community Services Society. 2011. SCC available at: http://scc.lexum.org/en/2011/2011scc44/2011scc44.html

Cappe, Mel, David Dodge, Ivan Fellegi, and Alex Himelfarb. 2010. Open letter to the Prime Minister. The Hill Times Online, Sept. 20. Available at: http:/hilltimes.com/page/view/censusissue-09-20-2010

role values play in policy studies and the intellectual and practical difficulty in dealing with them." 
Chase, Steven and Tavia Grant. 2010. Chief statistician asked to rethink census for 2016. Globe and Mail, 11 Feb. Available at: http://m.theglobeandmail.com/news/politics/chief-statistician-asked-to-rethink-censusfor-2016/article1904832/?service $=$ mobile

Cohen, Marsha, and Paul C. Hébert. 2010. Editorial: Ideology trumps evidence with new voluntary survey. Canadian Medical Association Journal 182(12): E541. Available at: http://www.cmaj.ca/content/182/12/E541. full.pdf + html (This article was initially published and available on line 15 July).

Collins, Harry, and Robert Evans. 2009. Rethinking Expertise. Chicago: University of Chicago Press.

Dillon, Lisa. 2010. The value of the long form census for long term national and international research. Canadian Public Policy 36(3):389-393.

Douglas, Heather E. 2009. Science, Policy and the Value-Free Ideal. Pittsburgh: University of Pittsburgh Press.

Fafard, P. 2008. Evidence and Healthy Public Policy: Insights from Health and Political Sciences. Canadian Policy Research Networks and National Collaborating Centre for Health Public Policy, May 2008. Available at: http://www.cprn.org/documents/50036 EN.pdf

Green, David A., and Kevin Milligan. 2010. The importance of the long form census to Canada. Canadian Public Policy 36(3):383-388.

Hambrick, Ralph S. Jr. 1998. Expert advice for policy choice: Analysis \& discourse. Public Administration Review 58(6):533. Academic OneFile. Web. 31 July 2011.

Himelfarb, Alex. 2010. Former Chief Statistician Munir Sheikh's resignation was a brave and admirable act. The Mark, 23 July. Available at: http://www. themarknews.com/articles/1921-a-professional-public-servant-resigns

Kincaid, Harold, John Dupré, and Alison Wylie, eds. 2007. Value-Free Science? Ideals and Illusions. Oxford: Oxford University Press.

Kitcher, Philip. 2001. Science, Truth and Democracy. Oxford: Oxford University Press.

Latour, Bruno. 2003. "Why has critique run out of steam?" Critical Inquiry 20(2):225-248. 2004. Politics of Nature: How to Bring the Sciences into Democracy. Translated by Catherine Porter. Cambridge, MA: Harvard University Press.

Mannheim, Karl. 1936. Ideology and Utopia: An Introduction to the Sociology of Knowledge. Translated by Louis Wirth and Edward Shils. New York: Harcourt, Brace \& World, Inc.

Nature Editorial. 2010. Save the census: The Canadian government should rethink its decision to change the way census data are collected. Nature 
466(7306), 29 July: 532. Available at: http://www.nature.com/nature/ journal/v466/n7306/full/466532a.html

Raatikainen, Panu. 2006. The scope and limits of value-freedom in science. In Heikki J. Koskinen, Sami Pihlström, and Risto Vilkko, eds., Science - A Challenge to Philosophy? Frankfurt am Main: Peter Lang GmbH.

Rasmussen, Lisa, ed. 2005. Ethics Expertise: History, Contemporary Perspectives, and Applications. Dordrecht, NL: Springer Verlag.

Ricoeur, Paul. 1975. Lectures on Ideology and Utopia. Chicago: University of Chicago Press.

Russell, J., T. Greenhalgh, E. Byrne, and J. McDonnell. 2008. Recognising rhetoric in healthcare policy analysis. Journal of Health Services and Research Policy 13(1):40-46.

Saurette, Paul. 2010. When smart parties make stupid decisions. The Mark, 23 July. http://www.themarknews.com/articles/1907-when-smart-partiesmake-stupid-decisions

Selinger, Evan, and Robert P. Crease, eds. 2006. The Philosophy of Expertise. New York: Columbia University Press.

Sheikh, M. 2010. July 21 resignation letter. Available at http://www.cbc.ca/ news/politics/inside-politics-blog/2010/07/censuswatch-and-thats-allhe-wrote-munir-sheikh-resigns-as-chief-statistician.html

Simpson, Jeffrey. 2010. Stats crash at the corner of ideology and reason. Globe and Mail, 23 July. Available at: http://www.theglobeandmail.com/ news/opinions/stats-crash-at-the-corner-of-ideology-and-reason/article1648768/

Skerry, Peter. 2000. Counting on the Census? Race, Group Identity, and the Evasion of Politics. Washington, DC: Brookings Institution Press.

Thompson, Debra. 2010a. Ideology, autonomy and the census. Mowat Centre for Policy Innovation. Available at: http://www.mowatcentre.ca/opinions. php?opinion ID $=42$

2010b. The politics of the census: Lessons from abroad. Canadian Public Policy 36(3):377-382

Veal, Michael. 2010. 2B or not 2B? What should have happened with the long form census? What should happen now? Canadian Public Policy 36(3): 395-399.

Veatch, Robert M. 1973. Generalization of expertise: Scientific expertise and value judgments. Hasting Center Studies 1:29-40.

2005. Expertise in public policy formation. In Lisa Rasmussen, ed., Ethics Expertise: History, Contemporary Perspectives, and Applications. Dordrecht, NL: Springer Verlag.

Yeo, M. 2010. Respect for privacy and data protection not the same thing. Hill Times 1053, August 30, p. 19. 
Michael Yeo is an associate professor of Philosophy at Laurentian University. His main area of expertise and research is professional ethics and health policy. Recent publications relevant to this article include: "Propaganda and Surveillance in George Orwell's Nineteen Eighty-Four: Two Sides of the Same Coin. Global Media Journal - Canadian Edition, 3(2), 2010: 49-66, http://www. gmj.uottawa.ca/1002/v3i2 yeo.pdf and Yeo, Michael, Emery, J.C. Herbert, and Kary, Dan. 2009. The Private Insurance Debate in Canadian Health Policy: Making the Values Explicit. SPP Research Paper: The Health Series, The School of Public Policy, University of Calgary, Volume 2, Issue 3, June. 2009. http:// policyschool.ucalgary.ca/?q=content/private-insurance-debate-canadian-healthpolicy-making-values-explicit myeo@,laurentian.ca 